\title{
Collective climate action and networked climate governance
}

\author{
Jale Tosun \\ Institute of Political Science, Heidelberg University \\ Bergheimer Straße 58, 69115 Heidelberg, Germany \\ Phone: +49 622154 3726, Fax: +49 6221542896 \\ Jale.tosun@ipw.uni-heidelberg.de \\ Jonas J. Schoenefeld \\ Tyndall Centre for Climate Change Research, School of \\ Environmental Sciences, University of East Anglia, Norwich \\ Research Park, Norwich NR4 7TJ, UK
}

This is the peer reviewed version of the following article: Tosun, J. and Schoenefeld, J. J. (2017), Collective climate action and networked climate governance. WIREs Clim Change, 8: n/a, e440. doi:10.1002/wcc.440, which has been published in final form at http://onlinelibrary.wiley.com/doi/10.1002/wcc.440/abstract. This article may be used for noncommercial purposes in accordance with Wiley Terms and Conditions for Self-Archiving.

\begin{abstract}
Scholarship in International Relations has witnessed that the traditional concept of hierarchically organized global climate governance is joined by a network model of decentralized governance, which involves multiple actors. New actors performing networked climate governance include national governments, subnational organizations like cities, international organizations, corporations, epistemic communities, and civil society organizations. An insightful literature on networked climate governance has advanced our conceptual understanding of this empirical phenomenon. In parallel, rapidly growing research in psychology, sociology, and economics, and related disciplines sheds light on factors that contribute to individuals' willingness to engage in collective climate action. This article reviews these seemingly disparate strands of literature and aims to build bridges between them. We focus on the factors underlying individuals' decisions to participate in local-level climate initiatives or grassroots organizations - including, for example, renewable energy cooperatives. Such initiatives are increasingly important parts of networked climate governance. Thus, networked governance can be conceived of as an opportunity structure for collective climate action, which may in turn influence citizens' decisions to participate. Given the urgency to address climate change, this approach adds a critical novel perspective to on-going debates about effective governance arrangements.
\end{abstract}

Keywords: collective climate action; engagement; multi-stakeholder partnerships; networked climate governance; opportunity structure; participation; pro-environmental behaviour. 


\section{Introduction}

After years of stalemate in international climate negotiations, ${ }^{1}$ governments reached a new and universal climate change agreement to govern the post-Kyoto era at the 21st Conference of the Parties (COP) to the United Nations Framework Convention on Climate Change (UNFCCCC) in Paris. The Paris Agreement not only aims to limit global warming to 'well below $2{ }^{\circ} \mathrm{C}$ above pre-industrial levels'; the Parties also agreed on 'pursuing efforts to limit the temperature increase to $1.5^{\circ} \mathrm{C}^{\prime}$. Reaching this goal will require constant action and strong commitments from state and a range of other actors in both the developed and developing world, since the new climate governance system is based on so-called national pledges. ${ }^{3}$ Moreover, there is consensus that incremental policy change will not suffice to respond to climate change, necessitating a society-wide transformation. ${ }^{4,5}$ This requires fundamental changes in production and consumption patterns, ${ }^{6}$ thereby indicating that responses to climate change require broad support from collective actors in the economy, from society and from individuals alike. ${ }^{7,8}$

Today, global climate governance includes actors such as governments, international organizations and cities along with private actors such as corporations, epistemic communities, and civil society organizations. ${ }^{9,10}$ While the global climate governance architecture is fragmented and leads to different degrees of governance performance ${ }^{11}$ this new structure has noticeably increased the opportunities of private actors to participate in international climate politics. ${ }^{12-14}$ However, triggering social change in response to climate change requires more far-reaching approaches, which calls for a greater involvement of citizens in climate governance. ${ }^{4-6,8,14}$ Drawing on different strands of literature, this review contends that citizens play an increasingly important role in transnational climate governance with a growing number of citizen climate initiatives, which are consequently driven by the motivation of individuals to engage in collective climate action. ${ }^{5,7,14}$ Having said that, we recognize that there is a specific literature - which is not reviewed here - elaborating on who expects individuals to get involved, what these actors' motivations are to mobilizing individuals, and how they facilitate and govern the individuals' involvement. ${ }^{15,16}$

Individuals can support climate protection by changing their consumption behaviour, signing petitions, or other forms of political activism, to name but a few examples. Another - and arguably more effective ${ }^{17}$ - way to bring about system-wide transformations in response to climate change entails collective action. ${ }^{14,18-25}$ Collective climate action such as neighbourhood-based climate protection initiatives is effective in three ways: First, membership in such citizen climate initiatives facilitates social learning and therefore brings about changes in the individuals' attitudes and 
behaviour; $5,6,19,20$ second, climate initiatives can pave the way for policy innovations; ${ }^{28-30}$ third, especially institutionalized initiatives can influence climate politics as a collective actor. ${ }^{14,20,22,31}$ With regard to the third point, the new global architecture of climate governance promises more institutional venues and therefore more influence to citizen climate initiatives. We focus on institutionalized groups of individuals which are also addressed by the literatures on transnational advocacy or discourse networks, ${ }^{32,33}$ advocacy coalitions, ${ }^{34,35}$ and epistemic communities. ${ }^{36}$ In this context, it should be noted that not all aspects of individuals and their respective behaviour apply directly to collective actors, even though certain aspects of broader questions on collective action do transpire.

Building on this premise, this review attempts to bring together two seemingly disparate research areas on collective climate action and networked climate governance with a view to advance both literatures and showcase the value of inter-disciplinary research. Learning about factors stimulating engagement in collective climate action provides valuable lessons for scholarship on networked climate governance on how to increase the effectiveness and inclusiveness of this governance mode. The study of collective climate action can benefit from acknowledging networked governance as an opportunity structure for collective climate action. In line with McAdam, we define opportunity structures as exogenous factors that limit or empower collective action. ${ }^{37}$ While McAdam concentrates on the political opportunity structures (i.e. openness of the institutionalized political system; stability of elite alignments; presence or elite allies; repression exercised by the state), our notion of opportunity structure is broader and encompasses any structures and incentives at the national or international level that encourage or discourage collective action. Our definition echoes the role Adger ${ }^{22}$ assigns to the state in facilitating specific behavioural patterns.

The overall aim of this review is to demonstrate that both literatures constitute pieces of the same puzzle, which is about how we can adequately respond to the challenges of climate change. The key difference between the literatures concerns their levels of analysis, which at the same time also provides an opportunity for merging them. We first focus on the contributions the literatures make individually for solving this puzzle. The major strength of this review, however, stems from the second step, that is, its attempt to illustrate the complementarity of the two literatures. ${ }^{13,14,22}$ By conceiving networked climate governance as an opportunity structure through which collective climate action defined as groups of individuals participating in the climate regime - can be facilitated, we strive to improve our understanding of how we can stimulate necessary processes of social change. 


\section{MAPPING THE TWO RESEACH AREAS}

Addressing anthropogenic climate change represents a collective action problem par excellence. There is general consensus that greenhouse gas (GHG) emissions - most importantly carbon dioxide (CO2)

- from human activities are the major drivers of global warming. ${ }^{38}$ Limiting the global temperature increase to below $2^{\circ} \mathrm{C}$ above pre-industrial levels requires 'a profound transformation of energy systems, through steep declines in carbon intensity across all sectors' ${ }^{39}$ Doing so, however, requires collective action, that is, joint activities in the pursuit of a common interest. ${ }^{14,20,22,31}$

Assuming that individuals would weigh the benefits and costs of particular actions, Olson cautioned that the former would not act collectively due to participation costs..$^{40}$ Individuals would rather abstain from collective action and benefit from the actions of others. This social dilemma is known as 'freeriding'. Based on this rationale, collective action for the provision of a common good critically depends on whether or not benefits can only be obtained from participation. Hardin then extended this reasoning by highlighting the importance of states (through providing binding rules) or markets (through providing property rights) for achieving collective action. ${ }^{41}$

In the case of climate change, the common pool resource at the centre of collective action may be understood as the relatively stable atmospheric conditions that have allowed natural and human activities to evolve. ${ }^{42}$ However, since Hardin's early assertion that markets or states are indispensable to produce common goods, other scholars have demonstrated both theoretically and empirically that there are other ways to overcome the collective action problem. Notably, Ostrom argued that carefully designed institutional arrangements can in some cases outperform states and markets to address collective action problems. ${ }^{43}$ Studying mainly small to medium-sized common-pool resource systems, the Ostrom showed that in many cases, actors can self-organize to build enduring management systems, and that these arrangements are likely to be especially successful if they follow a number of institutional design principles: clearly defined boundaries; congruence between appropriation and provision rules and local conditions; collective-choice arrangements; monitoring; graduated sanctions; conflict resolution mechanisms; minimal recognition of rights to organize; nested enterprises for common pool resources that are part of larger systems.

Remarkably, collective action problems can and do occur both among individuals and states, meaning that free-riding affects the production of common goods in both realms. Therefore, even though at first glance the two levels of analysis seem disparate, the deeper and recurring question about collective action connects them. Another commonality is that despite free-riding, individuals and 
states engage in cooperation. ${ }^{14,20,22,43}$ But the two do not necessarily march in tandem: even when international negotiations are gridlocked or ineffective, the decentralized nature of transnational climate governance provides an opportunity structure for non-state actors such as citizens' climate initiatives to engage in cooperation. ${ }^{1,43}$

\section{Collective climate action}

The first theoretical and empirical phenomenon that this review addresses is collective climate action. $14,20,22,31$ Wright et al. conceive collective action to occur any time when a person acts as a 'representative of the group and the action is directed at improving the conditions of the entire group ${ }^{4}{ }^{44}$ Van Zomeren et al. argued that the decision of individuals to engage in collective action can be based on their perception that the problem in question of a collective nature. ${ }^{45,46}$ In other words, individuals believe that joint effort can best solve the problem. Since both problem and solution are perceived at the group level, pro-climate action depends on group or collective efficacy beliefs.

The literature in environmental and social psychology differentiates between the intention to engage in collective climate action and the actual behaviour. ${ }^{47}$ While insightful research addresses both aspects, this review focuses on actual engagement in collective climate action since this is more compatible with the concept of networked climate governance and also more important with a view for the transformational changes needed to address climate change..$^{4,5,17,23}$ Collective climate action can target both climate change mitigation (i.e., efforts to limit global warming) and adaptation (i.e., responses to anticipated and present manifestations of climate change), and both forms have been analysed in the literature..$^{23,24,48}$ This review thereby focuses on mitigation-related collective climate action.

Collective climate action can take many different forms, including organizing and participating in citizen initiatives, boycotts and buycotts, and demonstrations or even riots. ${ }^{45,49,50}$ Here we are strictly interested in institutionalized and peaceful forms of collective climate action, which often but not exclusively emerge from local levels. From this perspective, we are most interested in grassroots groups working towards climate change mitigation. ${ }^{6}$ It should be noted that grassroots organizations are different from NGOs with regard to the possibilities they offer for collective action. ${ }^{51}$ Therefore, whenever we henceforth refer to collective climate action, we restrict our focus to that of citizen involvement in grassroots organizations at the subnational (mostly local) level. 
For example, citizen renewable energy cooperatives have proliferated as the dominant form of community-based energy initiatives in the last few years. ${ }^{18,52}$ Individual renewable energy cooperatives differ starkly in terms of organization, financing, and membership, ${ }^{53}$ but all cooperatives have in common that the members jointly govern renewable energy production facilities at the local or regional scale. Another example of community-based collective climate action is the Transition Towns movement, ${ }^{24}$ having started with an initiative in the town of Totnes in the United Kingdom in 2005. The Transition Towns movement focuses on the development of community-led responses to climate change and the finiteness of fossil fuels as well as the increasing social and economic sustainability. The essence of this initiative is to (re-)localize agriculture and food as well as energy production, use local building material and to invest in zero-energy housing, reduce waste, and consider new approaches to waste management. Communities that are interested in joining the movement must agree to a catalogue of 16 criteria, which refer to communication, constitutional aims, knowledge, skills, and working parameters. ${ }^{54}$

The Transition Towns movement is widely regarded as a success story due to its 'formalised international organisational structure and its wide geographical distribution ${ }^{\prime 38}$ This case highlights that even if grassroots organizations engage in climate action at the local level, they can diffuse to the regional, national, or international level. Another example is the Citizens' Climate Lobby, which is active internationally and consists of volunteers who engage with elected officials, the media, and the public in order to build support for climate protection measures.

\section{Networked Climate Governance}

Studies in International Relations and International Political Economy have traditionally focused on international climate negotiations and their outcomes in terms of producing a legally-binding global climate treaty. ${ }^{3,55-58}$ Given the negotiation outcomes, most studies concentrated on identifying the reasons for the failure of international cooperation. ${ }^{59,60}$ However, in the past decade politicians and political scientists had to acknowledge the proliferation of new actors and forms of global climate governance. ${ }^{1,9,11,61-64}$ Ostrom stressed that a range of actors at different governance scales may have more capacity and willingness to address climate change in a bottom-up fashion than previously assumed. ${ }^{61}$ This approach, in turn, generates a heterogeneous, or polycentric, pattern of governance, which appears to be emerging alongside and increasingly through UNFCCC-driven approaches. ${ }^{62-64}$ The main feature of the new pattern of governance is that the traditional concept of hierarchically organized global climate governance is complemented with a network model of decentralized global climate governance. ${ }^{65}$ 
The concept of networked governance refers to transnational climate partnerships that, according to Bäckstrand, can correspond to the following three types: governmental, private-to-private, and public-private (hybrid). ${ }^{66}$ Governmental climate partnerships involve public authorities such as government units, cities, or (units of) regional or international organizations. Cooperation in governmental climate partnerships is mostly achieved through soft forms of cooperation (e.g. by memorandum of understanding), such as in the case of the Regional Greenhouse Gas Initiative. ${ }^{9}$ Private-to-private partnerships involve non-state actors such as firms and/or NGOs that collaborate with other firms and/or NGOs. ${ }^{67,68}$ Prominent examples include the certification scheme of the Forest Stewardship Council and the Programme for the Endorsement of Forest Certification. ${ }^{69}$ Scholars have paid most attention to hybrid climate partnerships in which actors from the public and private sectors establish joint transnational networks with a set of governance objectives. ${ }^{70} \mathrm{~A}$ well-known example is the Clean Development Mechanism, where national governments hold the supreme authority, whilst private actors are responsible for the oversight and daily supervision of the project-based mechanism. ${ }^{71}$ In this review we closely follow Bäckstrand's conception of networked climate governance, which means focusing on transnational types of networked governance. ${ }^{66}$

The empirical reality which 'denotes a shift from intergovernmental regimes to public-private and increasingly private-private cooperation and global policy-making' furthermore justifies growing research on public-private partnerships. ${ }^{1}$ Drawing on the databases of transnational climate governance initiatives by cities, NGOs, firms, and other sub-state and non-state actors developed by Bulkeley et al. ${ }^{62}$ and Hoffmann, ${ }^{72}$ Hale and Roger ${ }^{68}$ arrive at 75 initiatives that primarily involve governance by sub-state and/or non-state actors. Not only is the considerable number of transnational climate partnerships interesting, but also - and even more - the fact that they are 'orchestrated' by states or international organizations. ${ }^{68}$ This finding resonates with Pattberg's analysis of some 232 public-private partnerships emerging from the 2002 Johannesburg World Summit on Sustainable Development, which showed that states dominate in terms of leadership and general membership. ${ }^{70}$

Do the different types of transnational climate partnerships contribute differently to global climate governance? Andonova et al. ${ }^{9}$ show that all three forms of transnational climate partnerships fulfil three governance functions: information-sharing, capacity building and implementation, and rulesetting. Bäckstrand even identifies four functions of transnational climate partnerships: advocacy, rule and standard setting, rule implementation, and service provisions. ${ }^{66}$ Despite differences in their 
composition, all three types of transnational climate partnerships can, in principle, fulfil the same types of functions, although there is variation in the specific instruments of which they make use.

Broadly speaking, transnational climate partnerships fulfil an important role in the global climate regime, as their purpose is to 'implement multilateral rules and targets in the UNFCCC'. ${ }^{66}$ There are additional factors to explain the influence of transnational climate partnerships on the negotiation outcomes. One possibility is provided by the Conferences of the Parties (COP), a vital component of the UNFCC process, and the increasing number of side events they attract. ${ }^{78}$

\section{Connecting climate action and networked governance}

Given our definition of collective climate action as individuals engaging with grassroots organizations active at the local level, the link to networked governance should be straightforward. Regardless of whether the climate actions operate at the local, regional, national, or international level, networked governance provides an opportunity structure for the involvement of these initiatives in transnational climate governance. Collins and Ison ${ }^{74}$ even go one step further to claim that the new global climate governance architecture means that the 'participation of citizens, groups, organizations and businesses is now an essential element to tackle climate change'.

In most cases, local initiatives form networks with other local initiatives and participate in networked governance as 'transnational networks' - a mode of operating that has also proven attractive for cities and municipalities that have formed their own networks (e.g. Energy Cities). ${ }^{68}$ Cities engage in transnational climate partnerships through their own networks, but also by participating in broader transnational networks such as the Climate Action Network. ${ }^{74}$ We can observe similar patterns for the participation of citizen climate initiatives in networked governance. The Transition Towns movement, for instance, very visibly participates in transnational climate partnerships. ${ }^{38,54}$ The European Federation for Groups and Cooperatives of Citizens for Renewable Energy and Energy Efficiency (REScoop.eu) is another collective action network at the local level, having formed a network to participate in transnational climate partnerships. In short, grassroots organizations are increasingly taking part in networked climate governance..$^{72,76,77}$

Given the growing importance of non-state actor involvement in global climate politics, there has been increasing interest in their agency and authority as well as their legitimacy. ${ }^{78}$ With regard to grassroots movements, we focus on effectiveness and legitimacy considerations. We begin with the concept of legitimacy, which Bäckstrand ${ }^{66}$ - in the specific context of networked governance -conceives to result 
from accountability. More precisely, she distinguishes between participatory accountability (i.e., the representation of various stakeholders), transparency, and the availability of monitoring mechanisms. Here, we focus on the first aspect, namely to what extent a wide range of stakeholder groups can formally participate in the network (i.e. participatory accountability). Growing numbers of grassroots organizations are expected to increase the inclusiveness of transnational climate partnerships and therefore their legitimacy. With regard to the effectiveness of grassroots movements involved in transnational climate partnerships, the assessment criteria are 'the products and activities partnerships produce and the behavioural changes that can be attributed to these activities'. ${ }^{70}$

Thus far, few studies have systematically assessed the success and failure of grassroots innovations addressing climate change. ${ }^{38}$ However, some have argued that grassroots organizations potentially increase the effectiveness of networked governance. Hale, ${ }^{75}$ for instance, argues that such initiatives can successfully mobilize individuals to bring about the necessary social change to address climate change. Building on the literature on social innovation, Seyfang and Smith ${ }^{6}$ find that 'grassroots innovations appear good at creating alternatives for sustainable development, but they do not connect forcefully with mainstream socio-technical regimes'. Put differently, grassroots organizations are perceived as drivers of social innovation and social learning. ${ }^{20}$ Given the limited discussion of how grassroots organizations may increase the effectiveness of networked climate governance, this is certainly a promising avenue for future research.

All in all, drawing on existing research, ${ }^{12-14}$ we believe that there is a connection between collective climate action and networked climate governance, which we seek to explore in greater detail in this review. By systematically combining insights provided by the literatures on collective climate action and networked climate governance, we should be able to generate a significantly improved understanding of the drivers of and barriers to transformational social change that have proven necessary in responding to climate change. ${ }^{4,23}$

\section{DETERMINANTS OF INDIVIDUAL PARTICIPATION IN COLLECTIVE CLIMATE ACTION}

Given that the devastating consequences of climate change, the contribution of human activities, and the difficulties of governments in adopting adequate policy responses manifest ever more strongly, civil society has become an important source of climate policy innovations and collective climate action. ${ }^{67}$ But what motivates the individual to engage in such group-level collective action? This section addresses this research question by reviewing theories of behaviour change and pathway 
models to collective climate action. These scholarly debates offer insights into why individuals may or may not participate in actions at the group level.

\section{Theories of behaviour change}

How can we motivate individuals to take pro-environmental actions? This question has been addressed by a vast corpus of literature. ${ }^{5}$ One of the most prominent explanations has been that individuals do not participate in pro-environmental actions due to their lack of information. ${ }^{79}$ The corresponding literature argues that filling this information deficit should stimulate individual behaviour change. However, the simple view that providing people with information on climate change science will lead to direct and significant behaviour change in a linear way has been challenged quite early in the literature, as other factors such as pre-existing knowledge and structural constraints influence how individuals process and act on such information. ${ }^{80}$ This is, of course, not to say that public climate change education is unnecessary and it certainly remains an important part of climate change governance, but precisely how and to whom one communicates influences how individuals receive and process information. ${ }^{81}$

A key issue with climate change is that it is often perceived as hardly relevant to the individual's daily lives. ${ }^{82} \mathrm{~A}$ suggested remedy thus involves tailoring climate change messages in order to highlight its proximal consequences. Yet Brügger et al. ${ }^{83}$ explain that the effect of more localized climate change information depends very much on how that information interacts with the receiving individuals' general characteristics and how they process that information. For example, proximal information may act as a deterrent to individuals who value wider communities and the environment. Furthermore, Schoenefeld and McCauley ${ }^{84}$ show that empirical evidence does not support a straightforward, self-interest based theorization of this issue. In fact, people with more self-interested value orientations who received local climate information were found to disengage from climate change action and policy support, producing a 'reactance effect'. Thus, simply highlighting the local effects of climate change is unlikely to unequivocally stimulate action. Making such approaches effective requires a deep contextual understanding of the target audience. ${ }^{83}$

In a similar vein, moving climate change closer to people by highlighting potential co-benefits of climate change policy ${ }^{61,85}$ has generated mixed empirical evidence. Some researchers indeed found that individuals - particularly those who were already concerned about climate change - responded positively to re-framing climate change by, for example, focusing on public health benefits. ${ }^{81}$ But 
others found the opposite, even when taking into account pre-existing individual characteristics such as beliefs in the gravity of climate change, climate change awareness or political ideology. ${ }^{86}$

An informational intervention that has received considerable high-level attention by policy-makers is the 'nudge' approach popularized by Thaler and Sunstein. ${ }^{87}$ Their argument goes that because humans have limited cognitive capacity to process information and often rely on heuristics in their decisionmaking, small interventions, such as choosing default options when presenting a range of choices (e.g., making double-sided printing a default option) can have significant positive influences in a range of fields, possibly including climate change..$^{88,89}$

The second strand of literature examines the role of individual psychological drivers of behaviour change including values, attitudes, beliefs, and concerns. Values, or 'enduring belief[s] that a specific mode of conduct or end-state of existence is personally or socially preferable to an opposite or converse mode of conduct or end-state of existence', ${ }^{90}$ correlate strongly and consistently with proenvironmental and pro-climate behaviour. As Corner et al. ${ }^{91}$ emphasize in their detailed review, individuals with 'self-transcendent' value orientations (such as caring about wider communities, or the environment) engage more in pro-environmental behaviour than people who privilege 'selfenhancing' values that focus on individual gain or status. ${ }^{84}$ Attitudes may be defined as 'a learned predisposition to respond in a consistently favourable or unfavourable manner with respect to a given object' ${ }^{92}$ Large-scale meta-analyses have shown that, in contrast to values, attitudes are less enduring and less linked with pro-environmental behaviour..$^{93}$ Given that attitudes are less engrained, other factors, such as knowledge or structural constraints to address climate change are likely to play important roles. ${ }^{94,96}$ Likewise, beliefs have been found to be weaker predictors of taking action than values..$^{92}$ However, it is worth noting that wider beliefs about science in general influence how people interact with climate change. Recent research has shown that giving people messages about rapid progress in science tends to reduce their willingness to engage in pro-environmental behaviour. ${ }^{96} \mathrm{By}$ the same token, beliefs and appeals about environmental justice (e.g., the distributions of environmental effects on different groups in society) have been shown to influence proenvironmental intentions. ${ }^{26}$ Finally, drawing on a survey of Swedish households, Nässén et al. ${ }^{97}$ show that concerns over environmental protection and climate change, inter alia, lower the individuals' consumption-accounted GHG emissions.

The third literature builds upon social norms as drivers of pro-environmental behaviour. ${ }^{5,20} \mathrm{~A}$ social norm may be defined as what individuals deem normal behaviour in any given situation. ${ }^{98}$ When used 
in informational interventions, norm-based messaging has been shown to strongly influence a range of individual decisions and behaviour related to climate change, including energy conservation or the use of environmental resources. ${ }^{99}$ This also holds true for a range of climate-change related behaviour, and norms are often stronger than a range of other drivers. ${ }^{23}$

Studies have shown that the most effective norm-based messages are those that correspond most closely with the characteristics of a group to which an individual belongs. ${ }^{100}$ The relationship between norms and pro-environmental behaviour is further mediated by how connected individuals feel to a particular group from which they draw their norms. ${ }^{101}$ However, using such descriptive social normsi.e., describing what other people do - can backfire, as people who perform better than the norm may adjust their behaviour towards what they perceive as normal - the so-called 'boomerang effect'. ${ }^{102}$ However, adding an 'injunctive norm', or a message that indicates what is normally considered desirable or 'good' behaviour, has been shown to reduce this effect. In sum, social norms have proven consequential in information-based interventions, but they must be handled carefully to avoid potentially backfiring.

There are also a range of additional variables that have been shown to influence pro-environmental behaviour and thus an individual's willingness to participate in group-level climate action. Newer studies highlighted that it is not only the variable of climate-related information- that is, factual knowledge - as such matters, but rather how the information is communicated and which emotions it induces. ${ }^{103}$ As Leviston et al. ${ }^{82}$ show in a recent study, people tend to associate a range of images with climate change, and some of these images have differing affective responses: Linking climate change with disaster appeared to generate higher emotional arousal than linking it with deserted landscapes. While tapping into human emotions can be crucial to help individuals understand the full moral dimensions of climate change risks, ${ }^{104}$ so far researchers have generally cautioned against fearbased appeals to stimulate action on climate change, as these have been shown to be potentially counterproductive as they can make people feel helpless and overwhelmed. ${ }^{7,47,105}$ However, Pidgeon and Fischhoff ${ }^{106}$ argue that 'appropriately framed emotional appeals can motivate climate action, given the right supporting conditions'. With regard to the latter, the authors, among others, stress the importance of identifying viable ways to act on climate change as well as invoking feelings of personal control and support of others. ${ }^{104}$

\section{Pathway Models}


Recently a strand of literature has developed that uses concepts in environmental and social psychology to investigate reactions to climate change that are closely associated with the work of Bamberg and collaborators. ${ }^{23-25,93}$ Accordingly, Bamberg et al. ${ }^{24}$ indicate four pathways leading to collective climate action. The first pathway builds on the reasoning of $\mathrm{Olson}^{40}$ and contends that individuals are more likely to participate in collective action if there is no other way for obtaining the associated benefits, that is, through selective incentives. The second pathway we already briefly sketched above: the collective efficacy pathway. The reasoning underlying this pathway is that rational individuals will participate in collective action if they perceive that the group as a whole is able to successfully organize and conduct collective actions. Closely related to this is the third pathway: groupbased emotions pathway. It reasons that 'individuals first appraise whether their disadvantage is group-level, then appraise whether the group disadvantage is fair, legitimate, and just. Appraising the collective disadvantage negatively evokes group-based anger, and motivates individuals to take collective action ${ }^{24}$ The fourth pathway refers to social identity theory, which is widely regarded as one of the most influential theories in social psychology. It rests on the assumption that individuals partly define themselves through group memberships, and come to think, feel, and act as group members. ${ }^{23}$ Given this basic reasoning, social identity theory has been linked with a wide range of behavioural outcomes that can be understood as occurring out of the joint interest of the group. From this, it follows that a strong sense of collective identity is needed for group members to engage in collective action. ${ }^{24}$

A further development of this perspective is the integrative social identity model of collective action (SIMCA) proposed by van Zomeren et al. ${ }^{46}$ These scholars propose three underlying drivers of collective action, namely the perceived existence of a social injustice; efficacy (related to behavioural control - see above); and identity. In other words, it is a model that integrates the efficacy, the emotions and the identity pathways. Importantly, this theory goes beyond assessing individual behaviours and their correlates precisely because it takes into account the effects of group identity and issues such as politicization. This matters because collective action is, per definition, a group activity typically undertaken to achieve a common aim. More recent research has not only validated this model, but also begun to add potential additional factors, such as social norms and sense of group identity and collective responsibility. ${ }^{23,107}$ Taken together, there is thus a strong indication that in addition to the factors discussed above, identity and affect play important roles in stimulating collective action to address climate change.

\section{INTEGRATING COLLECTIVE CLIMATE ACTION AND NETWORKED GOVERNANCE}


Studies in behavioural sciences often concentrate on the determinants of human behaviour. Our review summarized numerous factors that determine an individual's willingness to participate in locallevel climate action. Rather than stressing differences or incompatibilities between the approaches and variables reviewed, we follow Capstick et al. ${ }^{108}$ and emphasize numerous overlaps and complementarities. Adding to this important perspective, we argue that it is crucial to pay close attention to contextual factors influencing individual behaviour. This approach resonates with the broader argument that there are no general panaceas that will work irrespective of local governance contexts. ${ }^{109}$ This means that general lessons about the effects of information, values, norms, emotions, or identity emerging from relevant literatures need to be considered in specific governance contexts. ${ }^{110}$

Recent studies on collective climate action have taken the embeddedness of individuals in social contexts into account. ${ }^{23-25,45,46,111-113}$ We contend that developing a much deeper understanding of what drives individuals to participate in collective action needs to go one step further and pay attention to the 'extent to which state and other actors configure the fabric and the texture of daily life ${ }^{\prime 111}$ At the most basic level, the characteristics of political systems matter: Because democracies offer more opportunities for participation and initiative than autocracies, the former are likely better at stimulating collective climate action than the latter. ${ }^{15,16,47,114,115}$ Building on this line of thought, we argue that the changes in the global climate governance architecture and especially growing opportunities for non-state actor participation constitute an important contextual factor that is worth taking into consideration. ${ }^{14,22}$

More specifically, we argue that the notion of opportunity structure ${ }^{37}$ is a fruitful concept to link the literatures on collective climate action with studies of networked climate governance. The use of the concept of opportunity structures allows for constructing an overarching analytical perspective that echoes prominent political science theories. For example, the influential advocacy coalition framework holds that the attainment of political goals is determined by the actor coalitions' beliefs and resources, as well as the strategies they apply given the institutional venue in which they operate. ${ }^{33,34}$ By our understanding, group-level climate actions operate within the context of networked climate governance. We expect that transnational climate networks determine which strategies the groups choose to pursue their interests at the national and the international level. At the same time, we posit that knowledge regarding the existence of networked governance and the possibility to influence international climate politics affects the decision of individuals to join grouplevel initiatives. In what follows we concentrate on this second aspect. 
How do individuals become aware of the context in which they make decisions? They can either observe this context directly or indirectly. At the local level, for instance, people - especially those with extensive personal networks - can observe their socio-political and socio-technological context more easily. They can directly observe the need and the opportunity structure for engagement in climate action - such as, for example, starting an energy cooperative to supply their community energy.$^{18}$ At higher levels, however, individuals cannot directly evaluate their action context and thus rely on information from other sources. But this creates an important dilemma, because the empirical evidence on the effectiveness of climate change information and knowledge to stimulate collective action is mixed at best. A starting point to resolve this issue is that information effectiveness very much depends on the characteristics of receivers and at times on those of the communicators. ${ }^{81}$ Thus, singular and decontextualized information provision is unlikely to induce significant shifts in knowledge, beliefs and subsequent climate change-related behaviour. ${ }^{110}$

Communicating in context is thus an important way forward. For example, O'Neill and NicholsonCole $^{105}$ argue that communication approaches that account for individuals' 'personal points of reference' (e.g. by appreciating their attitudes, beliefs, and values) and address the local and regional context are more likely to enhance the individuals' engagement with climate change. But the mass media tend to represent climate change as a global action problem. ${ }^{114}$ Following the previous reasoning and considering the importance of the mass media in communicating climate change, ${ }^{116,117}$ one would expect that the emphasis placed on the global dimension of climate change could entail disengagement from collective climate action. As Wolf and Moser ${ }^{47}$ reason, the 'immensity of this 'global' problem versus individual actions' is likely to make people feel helpless and discourage them from participating in group-level action.

Carefully crafted strategic communication approaches can potentially address some of these difficulties. ${ }^{117}$ Individuals need to understand that transnational climate partnerships exist and how they function, but at the same time communicators need to remain cognizant of local contexts as well as the full range of psycho-social and contextual factors we discussed above. To recall, collective climate action through grassroots organizations is an integrative component of networked climate governance. ${ }^{62,66,70}$ Therefore, audiences need more systematic information about the global climate governance architecture and how the latter is linked with local-level action. However, when doing so, it matters immensely to take into account prevailing social norms, value orientations, pre-existing knowledge and other psycho-social variables, as well as the nature of wider social practices and the 
physical environment. ${ }^{5,13}$ For example, if there is already a social norm, or indeed a wider social practice to collaborate in other areas, and if people believe that climate change is a problem and value their natural environment as well as the well-being of other communities, and if the physical conditions are such that actions can reasonably be taken (e.g., there are feasible sources of renewable energies), then it makes sense to anchor any communication in these key community characteristics.

When thinking of communication, one may think of the mass media, but communication is also transmitted in other forms. For example, politicians may invite citizens to participate in climate actions and explain that their efforts are not confined to the local level, but will transpire to higher levels. Likewise, NGOs could communicate the nature of networked climate governance and how the existence of this structure helps to make a difference at the global level. Done in this way, improving knowledge about networked climate governance and potentially offering a range of other opportunities to engage could empower individuals to feel that their actions are meaningful and not confined to the local level, but that they can contribute - by participating in transnational climate networks - to solving the problem at the global level. ${ }^{6}$ Doing so may especially engage young people by showing them what they can do and how their actions have an impact beyond their neighbourhood. ${ }^{81}$

Again, the Transitions Town movement is a suitable example. While being a local initiative, the members are committed to networking with a view to expanding the movement's geographical scope. ${ }^{38,54}$ The fact that the individual movements are local provides an important venue for individual involvement, while strategic communication about the geographical spread and membership in new transnational climate partnerships additionally signals that impact reaches well beyond the local level.

The discussion above shows that there is an important connection between networked governance and research on the determinants of individual participation in collective climate action. To understand this connection, we need to conceive of networked climate governance as an opportunity structure, which may upscale local-level climate action to higher levels and encourage citizens' involvement. Given the complexity of global climate governance, however, it is important to explain opportunity structures in understandable ways, which bears some challenges. On the one hand, organizations participating in networked governance will need to invest in communication, but resource constraints may make doing so difficult. On the other hand, the approach requires some basic recognition of the new global climate governance architecture and the crucial role of individual actors through collective action. Mobilizing individuals through transnational climate partnerships 
calls for some agreement on and support for this new governance form by all actors involved, including states.

\section{FUTURE RESEARCH OPPORTUNITIES}

The reasoning above prompts three research questions to guide future research: the first one refers to the empirical testing regarding the postulated relationship between the contextual communication of the opportunity structures provided by networked governance and greater incentives for engagement in collective action. One would initially need to assess how much respondents know about existing governance networks and what other socio-psychological factors are relevant in driving collective action in a particular case (and whether there are any factors that extant literatures have not yet identified). Doing so will paint a much more detailed and sophisticated picture of the relative efficacy of a range of factors in stimulating collective action. It would also assist social learning as local initiatives go transnational; for, other groups would be able to gauge whether the key factors that led to success or failure elsewhere can be reasonably expected to be relevant to them. Subsequent analyses could then implement framing analyses ${ }^{103}$ to investigate whether or not the opportunity structures provided by networked governance influences individuals' willingness to engage in collective climate action. Doing so would particularly allow for testing which of the pathways discussed above drive collective climate actions most effectively, and what contextual factors matter most. To recall, Bamberg et al. ${ }^{24}$ identify four mechanisms through which individuals can be motivated to participate in group-level action, including selective incentives, rationality considerations, emotions, and social identity. Which of these pathways would be most effective? And how can they highlight that local-level climate action can transpire to the global level? These are questions worth investigating in future research.

The second area relates to the role of grassroots organizations in transnational climate partnerships. What is their influence vis-à-vis the other members of such networks that are arguably more powerful? Importantly, Uphoff ${ }^{51}$ systematically compared the participation of grassroots organizations and NGOs to show that they differ in their collective action possibilities, which we expect to be reflected in how they can participate in global climate governance. While there is a small but growing literature on the global diffusion of grassroots organizations, ${ }^{38}$ studies of networked climate governance have paid less attention to how exactly these organizations participate in networked climate governance via-à-vis the other members. Empirical data provided by Bulkeley et al., ${ }^{62} \mathrm{Hale}$ and Roger, ${ }^{68}$ Pattberg, ${ }^{70}$ and Hoffmann, ${ }^{72}$ could serve as a starting point for addressing this research question. Moreover, such a perspective would fit nicely with studies of transnational advocacy 
networks ${ }^{32}$ and epistemic communities. ${ }^{36}$ Another possibility for attaining an analytical value-added is to examine the effectiveness of transnational climate networks of varying compositions with a view to learn which of them is more influential in climate politics. This perspective would directly draw on the concept of advocacy coalitions, as put forward by Sabatier..$^{33}$

The third avenue for future research is about how participation in transnational climate partnerships may affect the internal structures and management of grassroots organizations. A first crucial step involves building networks at the regional, national or international level, a potentially resourceintensive activity. ${ }^{14}$ However, spreading ideas via networks may reduce the innovative capacity of grassroots organizations as they shift attention from content to organizational forms that can be easily adopted elsewhere. The rather specific issue focus of grassroots organizations ${ }^{51}$ generates important questions about what happens to these organizations once other actors in the governance network adopt their key messages or approaches. ${ }^{27}$ Again, the advocacy coalition framework ${ }^{33}$ may provide a useful analytical perspective for addressing this question since the essence of that framework is that actor coalitions compete against each other over political influence. From this perspective, grassroots organizations may lose their competitive advantage in such constellations if large parts of their demands are taken up by more powerful advocacy coalitions. Alternatively, more specific theories on climate policy innovations ${ }^{30}$ could be applied to address this research question.

\section{Conclusion}

This review had two key starting points: first, the empirical manifestation of a growing number of transnational climate partnerships; ${ }^{1,66,70}$ second, the realization that adequate responses to climate change require innovative policy responses ${ }^{30}$ and collective action ${ }^{14}$ on a variety of scales to bring about fundamental social change. ${ }^{4}$ While disparate at first glance, the new global climate governance architecture and collective climate action are connected to one another in important ways. As we argue above, networked climate governance serves as an opportunity structure for collective climate action in the sense that it may potentially encourage individuals to join group-level climate actions. The rationale underlying this expectation is that individuals who are, in principal, willing to participate in such initiatives (e.g. renewable energy cooperatives) may be even more convinced to do so when they realize that their actions transpire beyond the local level and when doing so matches their broader value, norm, and identity-based orientations. At the same time, networked governance requires social innovation $n^{6,27,28,38,77}$ and learning ${ }^{19,120}$ to produce effective climate change responses. Currently, comparatively few grassroots organizations - the form of local-level collective at the centre of this review - participate in networked climate governance. ${ }^{70}$ This might be due to two factors: First, 
it is a deliberate decision of grassroots organizations to concentrate their activities on the local level; second, generally only few grassroots organizations exist that could participate in transnational climate governance. With regard to the second explanation, we would argue that grassroots organizations could become better represented in networked climate governance if a greater number of individuals joined them. Different varieties of psychological literatures suggest that the individuals decisions to join such collective attempts are determined by their perceptions of the efficacy of collective action along with group-based emotions, social identity, as well as social norms and values. $^{23-25}$

Drawing on the psychological literature and combining it with studies in communication science, one way to potentially stimulate more collective action is to use communication. ${ }^{112}$ Providing individuals with information about the possibility that their local initiatives may contribute to transnational climate governance could spark their interest in getting involved. The information can be supplied by policy-makers or private actors such as NGOs either directly or indirectly by relying on the media. Yet one must bear in mind that the communication strategies used must be crafted carefully with a view to provide encouragement rather than discouragement. ${ }^{47}$ Moreover, we want to stress that this finding is derived from studies in the fields of communication science and psychology. Sociological research contends that beliefs, values, and attitudes are co-constituted by behaviour and social practices. Following this view, the media could not be assigned such a prominent role in encouraging individuals to participate in grassroots movements..$^{5,8,110,111,117,118}$ Rather, sociological research makes a plea for the 'generation and circulation of elements of which variously sustainable practices are made'.111

Greater participation in citizen climate initiatives may then stimulate the inclusiveness of networked governance - by expanding grassroots organization participation - and contribute to responding to climate change with the necessary ambition in terms of bringing about fundamental social change. Moreover, citizen climate initiatives could help to devise and spread more innovative climate policy measures, as multiple local-level initiatives are expected to contribute their respective views on the causes of climate change and the solutions they have experimented with. ${ }^{72}$ Using this analytical perspective would enrich the study of networked climate governance with key questions on climate policy innovation. ${ }^{30}$

More broadly, we argue that there is considerable interdependence between networked climate governance and collective climate action and we made an attempt to overcome existing disciplinary 
boundaries to advance this perspective. While the networked climate governance idea originated in International Relations and governance studies, collective climate action is associated with psychology, sociology, economics, and related disciplines. Despite the different levels of analysis (i.e., states or transnational climate partnerships versus individuals), recurring questions on the logic of collection action problems connects these literatures. Remarkably, the connection between networked climate governance and collective climate action we highlight partially resemble prominent theories of policy change in political science. Previously we discussed that networked climate governance can be conceived as an analytical concept known as institutional venue in the advocacy coalition framework, ${ }^{33,34}$ which determines how different actor groups interact with and compete against each other over political influence. The individuals can be accommodated in this framework in such a way that they decide whether and which advocacy coalition to join depending on how they perceive the institutional venues. Exploring and potentially strengthening this link will greatly enrich our current understanding of climate governance and ultimately contribute to its effectiveness.

As stated above, the core objective of this review was to build bridges between different types of literatures and levels of analysis. Given this goal we did not pay attention to contributions within the respective literatures, which represent more controversial views or stress uncertainties inherent to the theoretical lenses applied. We focused on individuals and the structures that surround them, but acknowledge this is a somewhat limited analytical perspective. Arguably, conceptualising individuals as atomistic, rational actors, or by contrast as entirely constrained by institutions or discourses are extreme ends of an extensive continuum. We believe that depending on the issue and contextual circumstances, most cases will fall somewhere on this continuum (rather than the ends). In a world where everything is controlled by rigid and unmovable discourses, it seems futile to even begin to think of change emanating from individuals (but there are many examples where this does appear to happen, as we show in the article). By the same token, assuming that individuals are staunch, unconstrained rationalists who can make whatever choice they like under any circumstances is equally unreasonable. In fact, we show in numerous ways how a range of external factors influence individuals, at times in irrational ways. With any particular issue, it is task of sound social research to identify the opportunities and constraints emanating from the complex nexus of individuals, social structures, and other elements, such as characteristics of the material world. All are likely to play some role in transformational responses to climate change. ${ }^{4}$ 
We believe that the literatures we review in this article provide useful pointers for researchers to explore climate change-related issues with a view to individual, social structures, and the material world. Yet we would like to flag that there exist other theoretical perspectives and assessment of the empirical phenomena presented here and we invite future research to consider engaging with that literature in a view to complete the picture we presented.

Alongside our call to consider a multitude of theoretical perspectives when investigating the relationship between collective climate action and networked climate governance, there are several empirical research questions that warrant future attention. While we have already highlighted some of these in the previous section, we believe that investigating whether networked climate governance is helping grassroots organizations to become a more central players in climate politics, or whether these groups remain at the fringes, is of particular importance. ${ }^{6,27,49,121-123}$ In other words and following the insights offered by Pattberg: ${ }^{70}$ does a growing number of grassroots movements involved in transnational climate partnerships lead to new activities that then lead to behavioural changes? This is just one of many worthy research questions bringing together global climate governance and social change attained by individuals.

\section{Governance}

Governance can be understood as 'shaping society in desired directions'. ${ }^{110}$ While the state plays a key role in governing, ${ }^{30}$ most studies in governance are interested in why non-state actors take matters into their own hands and act as substitutes for or in collaboration with government. In other words, it is about the relationship and cooperation of state and non-state actors in solving societal problems. The past decades have witnessed an increase in the governance of common goods involving public and private - or state and non-state - actors. This phenomenon has been analysed by many different terms including private governance, civil regulation, voluntary governance, co-governance, transnational or global governance, or corporate social responsibility. ${ }^{10}$ Governance as a concept is also used in anthropology, communication science, economics, sociology, and psychology. In anthropology, the role of cultural values for the working of governance is addressed. In communication science, the role of political and social communication lies at the heart of governancerelated research. Transaction costs, as well as how governance can help to reduce them, has been examined by economists. Studies in sociology are interested in the complexity of how governance is achieved, and how social environment and institutional rules affects governance systems. Since governance is about behavioural steering, it is closely interconnected with psychological concepts such as nudging. ${ }^{87}$ 
Proposals for mobilizing individuals and society

The Climate CoLab project is a crowdsourcing platform where people discuss proposals for what to do about climate change. Under the heading 'How can we mobilize individuals and society to shift behaviours in order to address climate change?' numerous innovative proposals were presented. All proposals aim to connect global climate change individual and community values to promote the adoptions of climate-friendly behaviour. One of them is about sending messages to friends and family about climate change. Other suggestions target the community level and, for example, concern devising 'community-specific behaviour change communication and cascade messages through different organizations at that level'. One proposal calls for involving selected journalists in communicating the findings of climate science for increasing the public' attention to them. Another proposal is to create a global lottery to raise the funds necessary for mitigating climate change. A second network worth mentioning is Climate Outreach, which pursues the goal of extending the audience of knowledge about climate change through interactions and conversation that resonate with people's values. Climate Outreach targets new audiences, including the Centre-Right, faith groups, young people, and people who have been displaced as a result of climate change.

\section{Acknowledgment}

We thank the COST network INOGOV - Innovations in Climate Governance (IS1309) - for funding. We acknowledge helpful comments on an earlier version of this manuscript by two anonymous reviewers and Stephanie Austin. Felix Scholl deserves credit for editorial assistance and Hannah Schachter for language editing.

\section{References}

1. Biermann F. Beyond the intergovernmental regime: recent trends in global carbon governance. Current Opinion in Environmental Sustainability 2010, 2: 284-288.

2. Hulme M. 1.5 [deg] C and climate research after the Paris Agreement. Nature Climate Change 2016, 6: 222-224.

3. Michaelowa A. Opportunities for and Alternatives to Global Climate Regimes Post-Kyoto. Annual Review of Environment and Resources 2015, 40: 395-417.

4. Gillard R, Gouldson A, Paavola J, Van Alstine J. Transformational responses to climate change: beyond a systems perspective of social change in mitigation and adaptation. Wiley Interdisciplinary Reviews: Climate Change 2016, 7: 251-265.

5. Batel S, Castro P, Devine-Wright P, Howarth C. Developing a critical agenda to understand proenvironmental actions: contributions from Social Representations and Social Practices Theories. Wiley Interdisciplinary Reviews: Climate Change 2016, DOI: 10.1002/wcc.417.

6. Seyfang G, Smith A. Grassroots innovations for sustainable development: Towards a new research and policy agenda. Environmental Politics 2007, 16: 584-603. 
7. Lorenzoni I, Nicholson-Cole S, Whitmarsh L. Barriers perceived to engaging with climate change among the UK public and their policy implications. Global Environmental Change 2007, 17: 445-459.

8. Shove E. Beyond the ABC: climate change policy and theories of social change. Environment and Planning A 2010, 42: 1273-85.

9. Andonova LB, Betsill MM, Bulkeley H. Transnational climate governance. Global Environmental Politics 2009, 9: 52-73.

10. Tosun J, Koos S, Shore J. Co-governing common goods: Interaction patterns of private and public actors. Policy and Society 2016, 35:1-12.

11. Biermann F, Pattberg P, Van Asselt H, Zelli F. The fragmentation of global governance architectures: A framework for analysis. Global Environmental Politics 2009, 9: 14-40.

12. Abbott KW. The transnational regime complex for climate change. Environment and Planning C: Government and Policy 2012, 30: 571-90.

13. Abbott KW. Engaging the public and the private in global sustainability governance. International Affairs 2012, 88: 543-564.

14. Poteete, A.R., Janssen, M.A. and Ostrom, E. Working together: collective action, the commons, and multiple methods in practice. Princeton: Princeton University; 2010.

15. Gallagher, M. Foucault, power and participation. The International Journal of Children's Rights 2008, 16: 395-406.

16. Newig J, Fritsch O. Environmental governance: participatory, multi-level-and effective? Environmental Policy and Governance 2009, 19: 197-214.

17. Dixon J, Levine M, Reicher S, Durrheim K. Beyond prejudice: Are negative evaluations the problem and is getting us to like one another more the solution? Behavioral and Brain Sciences 2012, 35: 411-425.

18. Bomberg E, McEwen N. Mobilizing community energy. Energy Policy 2012, 51: 435-44.

19. Collins K, Ison R. Jumping off Arnstein's ladder: social learning as a new policy paradigm for climate change adaptation. Environmental Policy and Governance 2009, 19: 358-373.

20. Ostrom E. Collective action and the evolution of social norms. Journal of Natural Resources Policy Research 2014, 6: 235-252.

21. Whitmarsh L, Seyfang G, O'Neill S. Public engagement with carbon and climate change: to what extent is the public 'carbon capable'? Global Environmental Change 2011, 21: 56-65.

22. Adger WN. Social capital, collective action, and adaptation to climate change. In: Voss M, ed. Der Klimawandel: Sozialwissenschaftliche Perspektiven. Wiesbaden: VS; 2010, 327-345.

23. Rees JH, Bamberg S. Climate protection needs societal change: Determinants of intention to participate in collective climate action. European Journal of Social Psychology 2014, 44: 466473.

24. Bamberg S, Rees J, Seebauer S. Collective climate action: Determinants of participation intention in community-based pro-environmental initiatives. Journal of Environmental Psychology 2015, 43: 155-165.

25. Rees JH, Klug S, Bamberg S. Guilty conscience: motivating pro-environmental behavior by inducing negative moral emotions. Climatic Change 2015, 130: 439-452.

26. Reese G, Jacob L. Principles of environmental justice and pro-environmental action: A twostep process model of moral anger and responsibility to act. Environmental Science \& Policy 2015, 51: 88-94. 
27. Seyfang G, Haxeltine A. Growing grassroots innovations: exploring the role of communitybased initiatives in governing sustainable energy transitions. Environment and Planning $C$ : Government and Policy 2012, 30: 381-400.

28. Rodima-Taylor D. Social innovation and climate adaptation: Local collective action in diversifying Tanzania. Applied Geography 2012, 33: 128-134.

29. Aylett A. Networked urban climate governance: neighborhood-scale residential solar energy systems and the example of Solarize Portland. Environment and Planning C: Government and Policy 2013, 31: 858-875.

30. Jordan A, Huitema D. Innovations in climate policy: conclusions and new directions. Environmental Politics 2014, 23: 906-925.

31. Rootes C. Acting locally: The character, contexts and significance of local environmental mobilisations. Environmental Politics 2007, 16: 722-741.

32. Keck ME, Sikkink K. Transnational advocacy networks in international and regional politics. International Social Science Journal 199, 51: 89-101.

33. Sabatier PA. An advocacy coalition framework of policy change and the role of policy-oriented learning therein. Policy Sciences 1988, 21: 129-168.

34. Selin $\mathrm{H}$, VanDeveer SD. Political science and prediction: What's next for US climate change policy? Review of Policy Research 2007, 24: 1-27.

35. Bulkeley $H$. Discourse coalitions and the Australian climate change policy network. Environment and Planning C: Government and Policy 2000, 18: 727-748.

36. Haas PM. Introduction: epistemic communities and international policy coordination. International organization 1992, 46: 1-35.

37. McAdam D. Conceptual origins, current problems, future directions. In: McAdam D, McCarthy JD, Zald MN, eds. Comparative perspectives on social movements: Political opportunities, mobilizing structures, and cultural framings. Cambridge: Cambridge University Press; 1996, 23-40.

38. Feola $G$, Nunes R. Success and failure of grassroots innovations for addressing climate change: the case of the transition movement. Global Environmental Change 2014, 24: 232-250.

39. Deep Decarbonization Pathways Project. Pathways to deep decarbonization 2015 report. New York/Paris: SDSN - IDDR; 2015.

40. Olson M. The logic of collective action: Public Goods and the Theory of Groups. Cambridge, M.A.: Harvard University Press; 1965.

41. Hardin G. The tragedy of the commons. Science 1968, 162: 1243-1248.

42. Hansen J, Sato M, Kharecha P, Beerling D, Berner R., Masson-Delmotte V, Pagani M, Raymo M, Royer DL, Zachos JC. Target atmospheric CO2: Where should humanity aim? Open Atmospheric Science Journal 2008, 2: 217-231.

43. Ostrom E. Governing the commons. Cambridge, M.A.; Cambridge: Cambridge University Press; 1990.

44. Wright SC, Taylor DM, Moghaddam FM. Responding to membership in a disadvantaged group: From acceptance to collective protest. Journal of Personality and Social Psychology 1990, 58 : 994-1003.

45. van Zomeren M, Leach CW, Spears R. Protesters as 'passionate economists' a dynamic dual pathway model of approach coping with collective disadvantage. Personality and Social Psychology Review 2012, 16: 180-199. 
46. van Zomeren M, Postmes T, Spears R. Toward an integrative social identity model of collective action: a quantitative research synthesis of three socio-psychological perspectives. Psychological Bulletin 2008, 134: 504-535.

47. Wolf J, Moser SC. Individual understandings, perceptions, and engagement with climate change: insights from in-depth studies across the world. Wiley Interdisciplinary Reviews: Climate Change 2011, 4: 547-69.

48. Grothmann T, Patt A. Adaptive capacity and human cognition: the process of individual adaptation to climate change. Global Environmental Change 2005, 15: 199-213.

49. Seyfang $G$. The new economics of sustainable consumption: Seeds of change. Basingstoke: Palgrave Macmillan; 2009.

50. Pezzullo PC. Contextualizing boycotts and buycotts: The impure politics of consumer-based advocacy in an age of global ecological crises. Communication and Critical/Cultural Studies, 2011 8: 124-45.

51. Uphoff N. Grassroots organizations and NGOs in rural development: Opportunities with diminishing states and expanding markets. World Development 1993, 21: 607-622.

52. Hoffman SM, High-Pippert A. From private lives to collective action: Recruitment and participation incentives for a community energy program. Energy Policy 2010, 38: 7567-7574.

53. Yildiz Ö, Rommel J, Debor S., Holstenkamp L, Mey F, Müller JR, Radtke J, Rognli J. Renewable energy cooperatives as gatekeepers or facilitators? Recent developments in Germany and a multidisciplinary research agenda. Energy Research \& Social Science 2015, 6: 59-73.

54. Smith A. The transition town network: a review of current evolutions and renaissance. Social Movement Studies 2011, 10: 99-105.

55. Falkner R, Stephan H, Vogler J. International climate policy after Copenhagen: Towards a 'building blocks' approach. Global Policy 2010, 1: 252-262.

56. Andonova, LB, Alexieva A. Continuity and change in Russia's climate negotiations position and strategy. Climate Policy 2012, 12: 614-629.

57. Eckersley R. Moving forward in the climate negotiations: Multilateralism or minilateralism? Global Environmental Politics 2012, 12: 24-42.

58. Oberthür S, Roche KC. EU leadership in international climate policy: achievements and challenges. The International Spectator 2008, 43: 35-50.

59. Dimitrov, RS. Inside UN climate change negotiations: The Copenhagen conference. Review of Policy Research 2010, 27: 795-821.

60. Kilian B, Elgström O. Still a green leader? The European Union's role in international climate negotiations. Cooperation and Conflict 2010, 45: 255-273.

61. Ostrom E. Polycentric systems for coping with collective action and global environmental change. Global Environmental Change 2010, 20: 550-557.

62. Bulkeley H, Andonova L, Bäckstrand K, Betsill M, Compagnon D, Duffy R, Kolk A, Hoffmann M, Levy $D$, Newell $P$, Milledge $T$, et al. Governing climate change transnationally: assessing the evidence from a database of sixty initiatives. Environment and Planning C: Government and Policy 2012, 30: 591-612.

63. Keohane RO, Victor, DG. The regime complex for climate change. Perspectives on Politics 2011, 9: 7-23.

64. Jordan AJ, Huitema D, Hildén M, van Asselt H, Rayner TJ, Schoenefeld JJ, Tosun J, Forster J, Boasson EL. Emergence of polycentric climate governance and its future prospects. Nature Climate Change 2015, 5: 977-982. 
65. Newell P, Pattberg P, Schroeder H. Multiactor governance and the environment. Annual Review of Environment and Resources 2012, 37: 365-387.

66. Bäckstrand K. Accountability of networked climate governance: The rise of transnational climate partnerships. Global Environmental Politics 2008, 8: 74-102.

67. Green JF. Rethinking private authority: Agents and entrepreneurs in global environmental governance, Princeton, N.J.: Princeton University Press; 2014.

68. Hale $\mathrm{T}$, Roger $\mathrm{C}$. Orchestration and transnational climate governance. The Review of International Organizations 2014, 9: 59-82.

69. Pattberg P. Private governance and the South: lessons from global forest politics. Third World Quarterly 2006, 27: 579-93.

70. Pattberg P. Public-private partnerships in global climate governance. Wiley Interdisciplinary Reviews: Climate Change 2010, 1: 279-287.

71. Hickmann T. Private authority in global climate governance: the case of the clean development mechanism. Climate and Development 2013, 5: 46-54.

72. Hoffmann MJ. Climate governance at the crossroads: experimenting with a global response after Kyoto. Oxford, Oxford University Press; 2011.

73. Schroeder $\mathrm{H}$, Lovell $\mathrm{H}$. The role of non-nation-state actors and side events in the international climate negotiations. Climate Policy 2012, 12: 23-37.

74. Collins K, Ison R. Jumping off Arnstein's ladder: social learning as a new policy paradigm for climate change adaptation. Environmental Policy and Governance 2009, 19: 358-373.

75. Kern K, Bulkeley H. Cities, Europeanization and Multi-level Governance: Governing Climate Change through Transnational Municipal Networks. Journal of Common Market Studies 2009, 47: 309-332.

76. Hale S. The new politics of climate change: why we are failing and how we will succeed. Environmental Politics 2010, 19: 255-275.

77. Scott-Cato M, Hillier J. How could we study climate-related social innovation? Applying Deleuzean philosophy to Transition Towns. Environmental Politics 2010, 19: 869-87.

78. Lederer M. From CDM to REDD+ - What do we know for setting up effective and legitimate carbon governance? Ecological Economics 2011, 70: 1900-1907.

79. Moser SC., Dilling L, eds. Creating a climate for change. Cambridge: Cambridge University Press; 2006.

80. Whitmarsh L, O'Neill S, Lorenzoni I. Public engagement with climate change: What do we know and where do we go from here? International Journal of Media \& Cultural Politics 2013, 9: 7-25.

81. Corner A, Roberts O, Chiari S, Völler S, Mayrhuber ES, Mandl S, Monson K. How do young people engage with climate change? The role of knowledge, values, message framing, and trusted communicators. Wiley Interdisciplinary Reviews: Climate Change 2015, 6: 523-534.

82. Leviston Z, Price J, Bishop B. Imagining climate change: The role of implicit associations and affective psychological distancing in climate change responses. European Journal of Social Psychology 2014, 44: 441-454.

83. Brügger A, Dessai S, Devine-Wright $P$, Morton TA, Pidgeon NF. Psychological responses to the proximity of climate change. Nature Climate Change 2015, 5: 1031-1037.

84. Schoenefeld JJ, McCauley MR. Local is not always better: the impact of climate information on values, behavior and policy support. Journal of Environmental Studies and Sciences 2015, DOI: 10.1007/s13412-015-0288-y. 
85. Somanathan E, Sterner E, Sugiyama T, Chimanikire D, Dubash NK, Essandoh-Yeddu, JK, Fifita $S$, Goulder L, Jaffe A, Labandeira X, et al. National and Sub-national Policies and Institutions. In: IPCC [Edenhofer OR, Pichs-Madruga Y, Sokona E, Farahani S, Kadner K, Seyboth A, Adler I, Baum S, Brunner P, Eickemeier B, et al., eds.]. Climate Change 2014: Mitigation of Climate Change. Contribution of Working Group III to the Fifth Assessment Report of the Intergovernmental Panel on Climate Change, Cambridge: Cambridge University Press; 2014, 1141-1205.

86. Bernauer T, McGrath LF. Simple reframing unlikely to boost public support for climate policy. Nature Climate Change 2016. DOI: 10.1038/nclimate2948.

87. Thaler RH, Sunstein CR. Nudge: Improving decisions about health, wealth and happiness. New Haven, C.T.: Yale University Press; 2008.

88. Kallbekken S, Sælen $\mathrm{H}$. 'Nudging' hotel guests to reduce food waste as a win-win environmental measure. Economics Letters 2013, 119: 325-327.

89. House of Lords Science and Technology Select Committee. Behaviour Change: Second Report of Session 2010-2012. London: House of Lords; 2011.

90. Rokeach M. The nature of human values. New York: Free Press; 1973.

91. Corner A, Markowitz E, Pidgeon N. Public engagement with climate change: the role of human values. Wiley Interdisciplinary Reviews: Climate Change 2014, 5: 411-422.

92. Fishbein M, Ajzen I. Belief, attitudes, intention, and behavior. An introduction to theory and research. Boston: Addison-Wesley; 1975.

93. Bamberg S, Möser G. Twenty years after Hines, Hungerford, and Tomera: A new meta-analysis of psycho-social determinants of pro-environmental behaviour. Journal of Environmental Psychology 2007, 27: 14-25.

94. Whitmarsh L, Seyfang G, O'Neill S. Public engagement with carbon and climate change: to what extent is the public 'carbon capable'? Global Environmental Change 2011, 21: 56-65.

95. Fielding KS, Hornsey MJ, Swim JK. Developing a social psychology of climate change. European Journal of Social Psychology 2014, 44: 413-420.

96. Meijers $\mathrm{MH}$, Rutjens BT. Affirming belief in scientific progress reduces environmentally friendly behaviour. European Journal of Social Psychology 2014, 44: 487-495.

97. Nässén J, Andersson D, Larsson J, Holmberg J. Explaining the Variation in Greenhouse Gas Emissions Between Households: Socioeconomic, Motivational, and Physical Factors. Journal of industrial Ecology 2015, 19: 480-489.

98. Cialdini RB. Crafting normative messages to protect the environment. Current Directions in Psychological Science 2003, 12: 105-109.

99. Griskevicius V, Cialdini RB, Goldstein NJ. Social norms: An underestimated and underemployed lever for managing climate change. International Journal for Sustainability Communication 2008, 3: 5-13.

100. Goldstein, NJ, Cialdini RB, Griskevicius V. A room with a viewpoint: Using social norms to motivate environmental conservation in hotels. Journal of Consumer Research 2008, 35: 472482.

101. Masson T, Fritsche I. Adherence to climate change-related ingroup norms: Do dimensions of group identification matter? European Journal of Social Psychology 2014, 44: 455-465.

102. Schultz PW, Nolan JM, Cialdini RB, Goldstein NJ, Griskevicius V. The constructive, destructive, and reconstructive power of social norms. Psychological Science 2007, 18: 429-434. 
103. Spence A, Pidgeon N. Framing and communicating climate change: The effects of distance and outcome frame manipulations. Global Environmental Change 2010, 20: 656-667.

104. Roeser S. Risk communication, public engagement, and climate change: a role for emotions. Risk Analysis 2012, 32: 1033-1040.

105. O'Neill S, Nicholson-Cole S. Fear Won't Do It: Promoting Positive Engagement With Climate Change Through Visual and Iconic Representations. Science Communication 2009, 30: 355379.

106. Pidgeon N, Fischhoff B. The role of social and decision sciences in communicating uncertain climate risks. Nature Climate Change 2011, 1: 35-41.

107. Obradovich N, Guenther SM. Collective responsibility amplifies mitigation behaviors. Climatic Change 2016, 137: 307-319.

108. Capstick S, Lorenzoni I, Corner A, Whitmarsh L. Prospects for radical emissions reduction through behavior and lifestyle change. Carbon Management 2014, 5: 429-445.

109. Ostrom E, Janssen MA, Anderies JM. Going beyond panaceas. Proceedings of the National Academy of Sciences 2007, 104: 15176-15178.

110. Shove E, Walker G. CAUTION! Transitions ahead: politics, practice, and sustainable transition management. Environment and Planning A 2007, 39: 763-770.

111. Shove E, Walker G. Governing transitions in the sustainability of everyday life. Research Policy 2010, 39: 471-476.

112. Orru K, Lilleoja L. Contextual drivers of environmental values cross-culturally: evidence from Europe between 2004 and 2012. Studies of Transition States and Societies 2015, 7: 38-51.

113. Aiken GT. Prosaic state governance of community low carbon transitions. Political Geography 2016, 55: 20-29.

114. Olausson U. Global warming: global responsibility? Media frames of collective action and scientific certainty. Public Understanding of Science 2009, 18: 421-436.

115. Tosun J, Croissant. Policy Diffusion: A Regime-Sensitive Conceptual Framework. Global Policy 2016, DOI: 10.1111/1758-5899.12363.

116. Schmidt A, Ivanova A, Schäfer MS. Media attention for climate change around the world: A comparative analysis of newspaper coverage in 27 countries. Global Environmental Change 2013, 23: 1233-1248.

117. Moser SC. Reflections on climate change communication research and practice in the second decade of the 21st century: what more is there to say? Wiley Interdisciplinary Reviews: Climate Change 2016, 7: 345-369.

118. Shove E. Putting practice into policy: reconfiguring questions of consumption and climate change. Contemporary Social Science 2014, 9: 415-429.

119. Spurling N, McMeekin A, Shove E, Southerton D, Welch D. Interventions in practice: re-framing policy approaches to consumer behaviour. Manchester: Sustainable Practices Research Group; 2013.

120. Pelling $M$, High C, Dearing J, Smith D. Shadow spaces for social learning: a relational understanding of adaptive capacity to climate change within organisations. Environment and Planning A 2008, 40: 867-884.

121. Kern F, Howlett M. Implementing transition management as policy reforms: a case study of the Dutch energy sector. Policy Sciences 2009, 42: 391-408. 
122. Berkhout F, Smith A, Stirling A. Socio-technological regimes and transition contexts. In: Elzen $\mathrm{B}$, Geels FW, Green K, eds. System innovation and the transition to sustainability: theory, evidence and policy. Cheltenham: Edward Elgar; 2004, 48-75.

123. Raven R, Kern F, Verhees B, Smith A. Niche construction and empowerment through sociopolitical work. A meta-analysis of six low-carbon technology cases. Environmental Innovation and Societal Transitions 2016, 18: 164-180.

Further Reading

Bulkeley H, Newell P, eds. Governing climate change. London: Routledge; 2015.

Dunlap RE, Brulle RJ, eds. Climate change and society: sociological perspectives. Oxford: Oxford University Press; 2015.

Held D, Theros M, Fane-Hervey A, eds. The Governance of Climate Change - Sciences, Politics and Ethics. Oxford: Polity; 2013.

Hulme M. Why We Disagree about Climate Change. Cambridge: Cambridge University Press; 2010.

Nulman E. Climate change and social movements: civil society and the development of national climate change policy. Basingstoke: Palgrave Macmillan; 2015.

Whitmarsh L, Lorenzoni I, O'Neill S. Engaging the public with climate change: Behaviour change and communication. London: Routledge; 2012.

\section{Resources}

Climate Action Tracker: http://climateactiontracker.org

Climate CoLab: http://climatecolab.org

Climate Outreach: http://climateoutreach.org

Future Earth: www.futureearth.org

Innovations in Climate Governance: http://innogov.eu

Transition Towns: www.transitionnetwork.org 